\title{
Daily Life and Planning for the Future of Ageing People with Down Syndrome: Results from a National Study on Caregivers
}

\author{
Venusia Covelli' ${ }^{1}$ Erika Guastafierro ${ }^{2}$, Matilde Leonardi ${ }^{2}$ \\ ${ }^{1}$ STORIOSS Research Centre, e-Campus University, Novedrate, Como, Italy \\ ${ }^{2}$ Neurology, Public Health and Disability Unit, Fondazione IRCCS Istituto Neurologico Carlo Besta, Milan, Italy \\ Email: venusia.covelli@gmail.com
}

How to cite this paper: Covelli, V., Guastafierro, E. and Leonardi, M. (2020) Daily Life and Planning for the Future of Ageing People with Down Syndrome: Results from a National Study on Caregivers. Advances in Aging Research, 9, 95-115.

https://doi.org/10.4236/aar.2020.96008

Received: September 18, 2020

Accepted: November 6, 2020

Published: November 9, 2020

Copyright ( 2020 by author(s) and Scientific Research Publishing Inc. This work is licensed under the Creative Commons Attribution International License (CC BY 4.0).

http://creativecommons.org/licenses/by/4.0/

\begin{abstract}
Background: Limited research concerns the study of continuity in the future of the physical and social status of elderly people with DS that is when people who take care of them will not be there anymore ("after we have gone"). Objective: From a biopsychosocial perspective, to investigate the daily life of ageing people with Down Syndrome over 45 years old in order to identify the most important issues in better planning for their future. Methods: A cross-sectional Italian national study was carried out. An ad hoc questionnaire was administered to formal and informal caregivers of aging people with Down Syndrome. Results: 136 family members and health professionals were involved. Most of the people with Down Syndrome live at home, attend a daily center and do many activities. Most of them had never worked and she/he is not at all autonomous. $25 \%$ of caregivers declared that, nowadays, there is not planning for the future, and $30.9 \%$ of participants who planned their future collected information when it occurred (e.g. when the parents pass away). Conclusions: The aging of people with DS requires attention to the planning of their future. In order to better plan, it is necessary to avoid programming "in emergency", but for time, keeping in mind of the activities developed by the people, their abilities and all of the elements that have allowed them to live well up to a point of their life.
\end{abstract}

\section{Keywords}

Down Syndrome, Trisomy 21, Future Life, Ageing, Elderly, Biopsychosocial Approach

\section{Introduction}

Down Syndrome (DS) is considered the most common genetic cause of intellec- 
tual disability [1] [2]. Despite the well-known comorbidities [3] [4], it was estimated that people with DS will be living as long as the general population [5]. This is due to improvements in medical care and health services [6] [7] who have made that in the last 70 years life expectancy of people with DS has considerably increased by 50 years [8], from an average of 9 years in 1929 [9] to 60 years in 2002 [10] [11]. In comparison to the general population, people with DS start to age prematurely [12] and they can be considered as "old" at the age of 45 [13] [14] [15] [16]. DS is associated with a group of clinical manifestations of "accelerated aging": early-onset dementia, early-onset menopause, hearing and visual impairments, thyroid dysfunction, obesity, diabetes, sleep apnea, musculoskeletal problems, skin and hair problems [17]. The increase in life expectancy shows a greater decline in cognitive and functional ability in people with DS over 50 age compared to their peers without DS [18] [19] [20].

In addition to a lot of studies that focus on clinical features of people with DS, researchers have also investigated the quality of life of people with DS and their families [21] [22] [23] [24] [25]. As recently reported, changes in clinical conditions tend to limit daily activities and social participation of elderly individuals with DS [26]. In this study conducted in Rome on people with DS (93 of 518 over 45 years old), it was found that limitations in autonomy translated into limitations in social life. This is probably due to the fact that the majority of the sample was living with their family and only a few of them in a small community family house or in a large establishment that could be a stimulus to create social networks. Based on Bertoli et al. questionnaire [26], a recent study performed by Matthews and colleagues [27] assessed health, social communication, and daily living skills of adults with DS. The authors described the range of abilities and how increasing age contributes to functional abilities in a sample of 188 individuals who provide care of people with DS from 20 to 69 years old. In people with DS more than 40 years old (49 participants on 188 total sample), levels of independence, communication and social skills were lower than younger people with DS, and tend to decline after age 40 - 45. In Italy, as Bertoli stated, it was hypothesized that the decline was due to the lack of support services after completing school in Rome. This information about independence, communication and social skills is important for family members "in order to plan accordingly for the future to their adult with DS" [27]. Another study, carried out by interviewing 31 people with DS of more than 45 years, consistently with the biopsychosocial perspective, has taken into account the environmental factors, such as social relationships and social assistance, related to the person's health status that is relevant for the personal functioning of these persons [28]. Family members and health professionals involved with people with DS play an important role in their daily support but, sometimes, they seem to prevent their autonomy development. For this reason, there is a real need, for all people with DS, to provide increased opportunities for engagement in social activities [29].

Unlike the literature on the health conditions of ageing people with DS is remarkable, there is limited research concerned the continuity of their life into the 
future. It is important to investigate the future planning for persons with DS to ensure continuity of their status (health and social) despite the loss of their family members, that is when people who take care of them will not be there anymore ("after we have gone"). About this, in Italy, a recent law was introduced in response to a need from the families of people with disabilities to ensure a future for their loved ones if there are no longer those who care for them today. Planning for the future is important for everyone, but plans are especially essential for an individual with DS to ensure the continuity of many achievements from the previous years, both at life skills and at health conditions levels.

Based on these considerations and recent suggestions [27], the present study aimed to investigate the daily life of ageing people with DS over 45 years old in order to describe and identify the most important aspects we have to take into account when we are planning for their future. Within the biopsychosocial perspective, the present research is based on the WHO's International Classification of Functioning, Disability and Health (ICF) that focuses on a person's living conditions and the role of environmental factors in the creation of disability [30]. The ICF biopsychosocial perspective, conceptualizing the disability as a difficulty of functioning, might potentially represent a significant framework in government policies or clinical practice addressed to ageing persons with DS [31]. Since there are no questionnaires based on the bio-psycho-social perspective, the study has foreseen the construction of a specific instrument (DOQuest) for the evaluation of functioning and disability of ageing people with DS according to ICF's biopsychosocial approach. Family members and health professionals were involved to observe the presence of health facilities and policies that represent facilitators for a positive experience of ageing.

\section{Methods}

This study is part of a larger project entitled "DOSAGE: Functioning and disability measure of Ageing people with Down Syndrome: the creation of an instrument for a national and European implementation", coordinated by Neurological Institute Carlo Besta IRCCS Foundation in Milan, aims to construct a questionnaire (DOQuest) for the evaluation of functioning and disability of ageing people with DS according to ICF's biopsychosocial approach. The study was approved by the Institute's ethics committee and all participants signed an informed consent form.

\subsection{Participants}

Throughout two main associations of family members of people with DS in Italy, Anffas Onlus and AIPD, 136 family members and the health professionals who provided care for people with DS over 45 years were enrolled. Inclusion criteria are family members who take care of a person with DS over 45 years old (parents, siblings, other informal caregivers); health professionals who interact regularly with persons with DS over 45 years old (physician such as geriatrician, 
neuropsychiatrist; social health worker; psychiatric rehabilitation technician; occupational therapist; psychologist; psychiatrist; professional educator; social worker, etc.). Exclusion criteria: family members who take care of a person with DS under 45 years old; health professionals who interact regularly with persons with DS under 45 years old; participants who did not provide informed consent to participate in research.

\subsection{Instrument}

The questionnaire (DOQuest) was made ad hoc on the basis of focus group and systematic literature review results published elsewhere [16] [32], and of a pilot study [28]. DOQuest is composed by 136 questions, organized into 6 sections that are inspired by the ICF classification [30]. The first five sections are about people with DS: 1) demographics information; 2) health status and quality of life; 3) social activities and participation; 4) environmental factors, social network and care network; 5) planning of the future. The last section collected demographics information about family members and health professionals. A pilot version of DOQuest was previously submitted to 38 participants (family members or health professionals).

\subsection{Data Collection}

DOQuest was widespread in Italy by ANFFAS Onlus and AIPD that invited by email all their association's local sections to collect it. Each local association's section collected the disclosure document and its signed informed consent before filling out the questionnaire. Data collection was carried out between May 2015 and September 2015. Participants (family members or health professionals) had the opportunity to choose whether to complete the questionnaire: 1) on paper, by printing the questionnaire and informed consents sent via email, and sending it filled into the coordinator center by post; 2) online, by filling in the questionnaire via the appropriate link. Data collected were analyzed using SPSS 18.0 statistical software package (IBM, Armonk, NY, USA). The questionnaires were collected with the help of 45 local sections of ANFFAS and AIPD associations in over 15 Italian regions. The irregular distribution of the collected data did not allow the possibility of comparing the results by geographical area.

\section{Results}

\subsection{Data on Living Condition of Persons with Down Syndrome}

136 questionnaires were collected, of which 68 were filled out by family members and 68 by health professionals. Sociodemographic characteristics of the sample are presented in Table 1 . The questionnaires have referred to 136 people with DS above the age of 45 years, 61 females and 75 males, with an average age of 53.3 (Table 2). Information about where the persons with DS lived was also collected. As shown in Table 2, the majority of them were living at home with a family member $(66.1 \%)$ and $72.8 \%$ participated at a daycare center $(59.9 \%$ is a 
Table 1. Socio-demographic characteristics of family members and health professionals.

\begin{tabular}{|c|c|c|}
\hline Total sample $(\mathrm{N}=136)$ & Mean (range) & $\mathrm{N}(\%)$ \\
\hline \multicolumn{3}{|l|}{ Data collection } \\
\hline Northern Italy & & $86(63.3)$ \\
\hline Central Italy & & $44(32.3)$ \\
\hline Southern Italy & & $6(4.4)$ \\
\hline \multicolumn{3}{|l|}{ Family Members $(\mathrm{N}=68)$} \\
\hline Mean age (range) & $64.7(39-92)$ & \\
\hline Female & & $46(67.6)$ \\
\hline \multicolumn{3}{|l|}{ Relationship with the person with DS } \\
\hline Parents: Mean age (range) & $78.6(67-92)$ & $19(27.9)$ \\
\hline Siblings: Mean age (range) & $59.9(39-82)$ & $42(61.8)$ \\
\hline Family members: Mean age (range) & $59.8(39-78)$ & $7(10.3)$ \\
\hline \multicolumn{3}{|l|}{ Education } \\
\hline Primary school & & $9(36.8)$ \\
\hline Secondary school & & $11(16.2)$ \\
\hline High school & & $23(33.8)$ \\
\hline Degree & & $9(13.2)$ \\
\hline Master degree/higher & & $16(23.6)$ \\
\hline \multicolumn{3}{|l|}{ Marital status } \\
\hline Single & & $8(11.8)$ \\
\hline Married & & $44(64.7)$ \\
\hline Cohabitant & & $3(4.4)$ \\
\hline Divorced & & $3(4.4)$ \\
\hline Widow & & $10(14.7)$ \\
\hline \multicolumn{3}{|l|}{ Work conditions } \\
\hline Employee & & $31(45.6)$ \\
\hline Not employee & & $2(2.9)$ \\
\hline Retired to work & & $35(51.5)$ \\
\hline \multicolumn{3}{|l|}{ Health Professionals $(\mathrm{N}=68)$} \\
\hline Mean age (range) & $45.6(23-63)$ & \\
\hline Female & & $55(80.9)$ \\
\hline \multicolumn{3}{|l|}{ Education } \\
\hline Secondary school & & $2(2.9)$ \\
\hline High school & & $20(29.4)$ \\
\hline Degree & & $34(50.1)$ \\
\hline Master degree/higher & & $12(17.6)$ \\
\hline \multicolumn{3}{|l|}{ Marital status } \\
\hline Single & & $13(19.1)$ \\
\hline Married & & $42(61.8)$ \\
\hline Cohabitant & & $4(5.9)$ \\
\hline Divorced & & $9(13.2)$ \\
\hline \multicolumn{3}{|l|}{ Employment } \\
\hline Educators & & $52(76.5)$ \\
\hline Social health operators & & $7(10.3)$ \\
\hline Nurses & & $4(5.9)$ \\
\hline Psychiatric Rehabilitation Technicians & & $2(2.9)$ \\
\hline Social workers & & $2(2.9)$ \\
\hline Something else & & $1(1.5)$ \\
\hline
\end{tabular}


Table 2. Data of persons with Down syndrome.

\begin{tabular}{|c|c|}
\hline Total sample $(\mathrm{N}=136)$ & $\mathbf{N}(\%)$ \\
\hline \multicolumn{2}{|l|}{ Mean age (range) $53.3(45-67)$} \\
\hline Female & $61(44.9)$ \\
\hline \multicolumn{2}{|l|}{ Educational level } \\
\hline No one & $58(42.6)$ \\
\hline Primary school & $37(27.2)$ \\
\hline Secondary school & $36(26.5)$ \\
\hline High school & $1(0.8)$ \\
\hline Not specified & $4(2.9)$ \\
\hline Total & $136(100)$ \\
\hline \multicolumn{2}{|l|}{ Did helshe attend "special schools"? } \\
\hline No & $66(48.5)$ \\
\hline Yes, primary school & $50(36.8)$ \\
\hline Yes, secondary school & $8(5.9)$ \\
\hline Yes, high school & $2(1.5)$ \\
\hline I wouldn't know & $10(7.3)$ \\
\hline Total & $136(100)$ \\
\hline \multicolumn{2}{|l|}{ Legal guardianship/protection } \\
\hline Guardian ad litem & $73(53.7)$ \\
\hline Guardian or guardian of the person & $39(28.7)$ \\
\hline None & $22(16.1)$ \\
\hline Curator or guardian of the property & $2(1.5)$ \\
\hline \multicolumn{2}{|l|}{ Other } \\
\hline Total & $136(100)$ \\
\hline \multicolumn{2}{|l|}{ Economic income $e^{*}$} \\
\hline Disability pension and attendance allowance & $34(50.3)$ \\
\hline Reversibility of the maternal/paternal board & $17(25.1)$ \\
\hline Attendance allowance for civil disability & $8(11.5)$ \\
\hline Disability pension (age $18-65)$ & $6(9.4)$ \\
\hline Salary & $1(1.6)$ \\
\hline Inability pension & $1(1.0)$ \\
\hline Contributory pension & $1(1.1)$ \\
\hline Welfare benefits (more of 65 age) & $0(0.0)$ \\
\hline \multicolumn{2}{|l|}{ Where do they live? } \\
\hline At home with their families & $90(66.2)$ \\
\hline Social health community for people with disabilities (CSS) & $24(17.6)$ \\
\hline Nursing home for people with disabilities (RSD) & $9(6.6)$ \\
\hline Family home & $5(3.7)$ \\
\hline Nursing home (RSA) & $3(2.2)$ \\
\hline Flexible care residence (RAF) & $3(2.2)$ \\
\hline Protected apartment & $2(1.5)$ \\
\hline Total & $136(100)$ \\
\hline \multicolumn{2}{|c|}{ Has hel she always lived in the place you have just indicated above? } \\
\hline No & $75(55.1)$ \\
\hline Yes & $61(44.9)$ \\
\hline Total & $136(100)$ \\
\hline
\end{tabular}




\section{Continued}

\begin{tabular}{|c|c|}
\hline \multicolumn{2}{|l|}{ What are the reasons of his/ her change of residence? } \\
\hline $\begin{array}{l}\text { The caregiver who used to help him/her passed away } \\
\text { (one or both parents, siblings, formal caregiver) }\end{array}$ & $31(41.2)$ \\
\hline $\begin{array}{l}\text { The person or the people that used to assist him/her couldn't do it anymore } \\
\text { (e.g. old age parents, or misunderstandings between siblings) }\end{array}$ & $24(32.0)$ \\
\hline His/her family changed residence & $5(6.7)$ \\
\hline $\begin{array}{l}\text { His health condition has got worse and there was } \\
\text { urgent need for greater medical nursing assistance. }\end{array}$ & $4(5.3)$ \\
\hline The facility that sheltered him/her was no longer welcome. & $2(2.7)$ \\
\hline $\begin{array}{l}\text { The person with DS has asked for a move } \\
\text { (for example to live on his/her own or with his/her partner or in a foster home). }\end{array}$ & $2(2.7)$ \\
\hline I wouldn’t know & $2(2.7)$ \\
\hline Other & $5(6.7)$ \\
\hline Total & $75(100)$ \\
\hline \multicolumn{2}{|l|}{ Participation at a day care center } \\
\hline Yes & $99(72.8)$ \\
\hline No & $37(27.2)$ \\
\hline Total & $136(100.0)$ \\
\hline \multicolumn{2}{|l|}{ The kind of facility he/ she is attending is... } \\
\hline Social care center & $59(59.6)$ \\
\hline Educational center & $22(22.2)$ \\
\hline Rehabilitative nursing & $17(17.2)$ \\
\hline Professional center & $1(1.0)$ \\
\hline Total & $99(100.0)$ \\
\hline
\end{tabular}

${ }^{\star}$ Multiple responses.

social care center). Half of the sample had changed residence during their life because the caregiver who used to help them passed away (41.2\%) or the person that used to assist them couldn't do it anymore (32.0\%).

\subsection{Health Condition}

The second part of the questionnaire investigated the quality of life and the health status perceived by the family members and operators about the person with DS (Table 3). Of 136 responders, the $47.1 \%$ believed that the person with DS has good health, and $58.1 \%$ believed that their quality of life was good. Regarding the health status specifically, we founded several comorbidities (they reported an average of 6.3 comorbidities) and the frequent pathologies are intellectual disability, dry skin, soliloquy, cataracts, hypothyroidism, hearing loss, obsessive-compulsive disorders, refractive problems, gingivitis, flat foot valgus, hallux valgus, keratosis, depression, alopecia areata, mitral valve prolapse, osteoporosis, scoliosis, epilepsy, aortic insufficiency, and autoimmune hepatitis. Family members and health operators refer that the persons with DS usually take medicine for these pathologies (they take an average of 1.7 drugs/medications): hypothyroidism (15.6\%), keratosis (10.4\%), respiratory infections (6.1\%), dry skin (6.1\%), epilepsy (5.6\%), depression (5.6\%) and autoimmune hepatitis $(4.3 \%)$. 
Table 3. Health condition.

\begin{tabular}{|c|c|}
\hline Total sample N (136) & $\mathrm{N}(\%)$ \\
\hline \multicolumn{2}{|l|}{$\begin{array}{l}\text { In general, how do you evaluate the current state of health of the person with } \\
\text { DS? }\end{array}$} \\
\hline Very bad & $5(3.7)$ \\
\hline $\mathrm{Bad}$ & $16(11.8)$ \\
\hline Neither bad nor good & $42(30.9)$ \\
\hline Good & $64(47.1)$ \\
\hline Very good & $9(6.6)$ \\
\hline \multicolumn{2}{|l|}{$\begin{array}{l}\text { In general, how do you evaluate the current state quality of life of the } \\
\text { person with DS? }\end{array}$} \\
\hline Bad & $4(2.9)$ \\
\hline Neither bad nor good & $31(22.8)$ \\
\hline Good & $79(58.1)$ \\
\hline Very good & $22(16.2)$ \\
\hline \multicolumn{2}{|l|}{ Who is the person in charge of the person with DS healthcare assistance? } \\
\hline Primary health care: general medical examinations & $12(8.8)$ \\
\hline Secondary health care: medical examination with a specialist & $29(21.3)$ \\
\hline Free healthcare products like incontinence diapers, crutches, catheter, etc. & $1(0.7)$ \\
\hline Rehabilitation service & $33(24.3)$ \\
\hline Nursing home admission & $15(11.0)$ \\
\hline $\begin{array}{l}\text { Psychological and psychiatric assistance through mental health departments } \\
\text { (please specify): ............... }\end{array}$ & $15(11.0)$ \\
\hline \multicolumn{2}{|l|}{ Comorbidities* } \\
\hline Dry skin & $54(39.7)$ \\
\hline Cataract (H26) & $41(30.1)$ \\
\hline Hypothyroidism (E03) & $36(26.5)$ \\
\hline Blindness and low vision (H54) & $35(25.7)$ \\
\hline Refraction disorder & $27(19.9)$ \\
\hline Periodontitis & $26(19.1)$ \\
\hline Flat foot (M 21.4) & $25(18.4)$ \\
\hline Bunion & $24(17.6)$ \\
\hline Keratosis & $24(17.6)$ \\
\hline Gingivitis & $18(13.2)$ \\
\hline
\end{tabular}

${ }^{*}$ ICD-10 diagnosis codes related to the ten most frequent comorbidities reported by participants.

\subsection{Activities and Participation}

In the third part of the questionnaire we investigate the activities and the social participation of the person with DS (Table 4). This section demonstrates that people with DS in our sample are very engaged in the activities organized by the centers in which they live or by their families. In addition, we have explored the ability of the use of public transport and we discovered that most of them are not able to use transport independently but only on familiar routes. Regarding their health care, $56.3 \%$ of people with DS are not able to take care of their own health and they do not know how to take medicines themselves. From a relational point of view, they easily enter in relation with strangers, but generally (61.4\%) they 
Table 4. Activities and participations.

\begin{tabular}{|c|c|c|c|}
\hline Total sample N (136) & $\begin{array}{l}\text { Completely/ } \\
\text { Moderately }\end{array}$ & $\begin{array}{l}\text { A little/ } \\
\text { Not at all }\end{array}$ & Missing \\
\hline Learning ability and the application of acquired knowledge & $\mathrm{N}(\&)$ & $\mathrm{N}(\&)$ & $\mathrm{N}(\&)$ \\
\hline Is he/she able to read? & $48(35.3)$ & $88(64.7)$ & 0.0 \\
\hline Does he/she understand what he/she reads? & $41(30.1)$ & $92(67.6)$ & $3(2.2)$ \\
\hline Is he/she able to write? & $42(30.9)$ & $93(68.4)$ & 0.7 \\
\hline Is he/she able to do easy calculations? & $10(7.4)$ & $126(92.6)$ & 0.0 \\
\hline Is he/she able to make decisions that affect his/her daily life & $71(52.2)$ & $65(47.8)$ & 0.0 \\
\hline \multicolumn{4}{|l|}{ The capacity to perform tasks and general requests. } \\
\hline Is the person with DS able to perform a simple task? & $85(62.5)$ & $51(37.5)$ & 0.0 \\
\hline Is he/she able to perform articulated tasks within a group? & $72(52.9)$ & $63(46.3)$ & $1(0.7)$ \\
\hline $\begin{array}{l}\text { Is he/she able to complete articulated tasks independently, } \\
\text { such as getting up in the morning and prepare } \\
\text { himself to go out? }\end{array}$ & $61(44.9)$ & $75(55.1)$ & 0.0 \\
\hline Is he/she able to plan his/her own daily routine? & $44(32.4)$ & $92(67.6)$ & 0.0 \\
\hline \multicolumn{4}{|l|}{ Communication skills } \\
\hline $\begin{array}{l}\text { Is he/she able to manage a conversation } \\
\text { (to begin, to keep and to end a conversation)? }\end{array}$ & $49(36.0)$ & $87(64.0)$ & 0.0 \\
\hline Is he/she able to use a telephone? & $29(21.3)$ & $106(77.9)$ & $1(0.7)$ \\
\hline Does he/she know how to use the computer autonomously? & $21(15.4)$ & $115(84.6)$ & 0.0 \\
\hline Is he/she able to read the time on digital watches? & $44(32.4)$ & $87(64.0)$ & $5(3.7)$ \\
\hline $\begin{array}{l}\text { Is he/she able to read the time on analog watches } \\
\text { (with hands)? }\end{array}$ & $39(28.7)$ & $97(71.3)$ & 0.0 \\
\hline \multicolumn{4}{|l|}{ Capacities to take care of him/herself } \\
\hline Is the person with DS able to look after his/her own health? & $25(18.4)$ & $110(80.9)$ & $1(0.7)$ \\
\hline To what extent is he/she able to take medicines? & $46(33.8)$ & $85(62.5)$ & $5(3.7)$ \\
\hline To what extent is he/she able to wash her/himself? & $64(47.1)$ & $71(52.2)$ & $1(0.7)$ \\
\hline $\begin{array}{l}\text { To what extent is he/she able to manage urination and } \\
\text { defecation? }\end{array}$ & $97(71.3)$ & $38(27.9)$ & $1(0.7)$ \\
\hline To what extent is he/she able to manage menstruation? & $10(7.4)$ & $8(5.9)$ & $118(86.8)$ \\
\hline To what extent is he/she able to get dressed and get undressed? & $101(74.3)$ & $32(23.5)$ & $3(2.2)$ \\
\hline To what extent is he/she able to put one's shoes on? & $94(69.1)$ & $41(30.1)$ & $1(0.7)$ \\
\hline To what extent is he/she able to choose suitable clothing? & $57(41.9)$ & $79(58.1)$ & 0.0 \\
\hline To what extent is he/she able to use cutlery and eat food? & $117(86.0)$ & $17(12.5)$ & $2(1.5)$ \\
\hline $\begin{array}{l}\text { To what extent is he/she able to take a glass and raise it to } \\
\text { his/her lips and then drink the drink? }\end{array}$ & $125(91.9)$ & $11(8.1)$ & 0.0 \\
\hline \multicolumn{4}{|l|}{$\begin{array}{l}\text { Capacity to manage daily routine/ domestic life } \\
\text { (only if hel she live at home) }\end{array}$} \\
\hline $\begin{array}{l}\text { To what extent he/she is able to acquire daily goods } \\
\text { (for example choose food, drinks, dresses, } \\
\text { cleaning products etc.)? }\end{array}$ & $19(14.0)$ & $102(75.0)$ & $15(11.0)$ \\
\hline $\begin{array}{l}\text { to what extent is he/she able to prepare meals for } \\
\text { him/herself and the others (parents for example)? }\end{array}$ & $10(7.4)$ & $111(81.6)$ & $15(11.0)$ \\
\hline $\begin{array}{l}\text { to what extent is he/she able to do housework } \\
\text { (for example cleaning up, do the laundry)? }\end{array}$ & $29(21.3)$ & $91(66.9)$ & $16(11.8)$ \\
\hline $\begin{array}{l}\text { to what extent is he/she able to assist others } \\
\text { (his/her parents for example) if properly educated to do so? }\end{array}$ & $21(15.4)$ & $98(72.1)$ & $17(12.5)$ \\
\hline
\end{tabular}




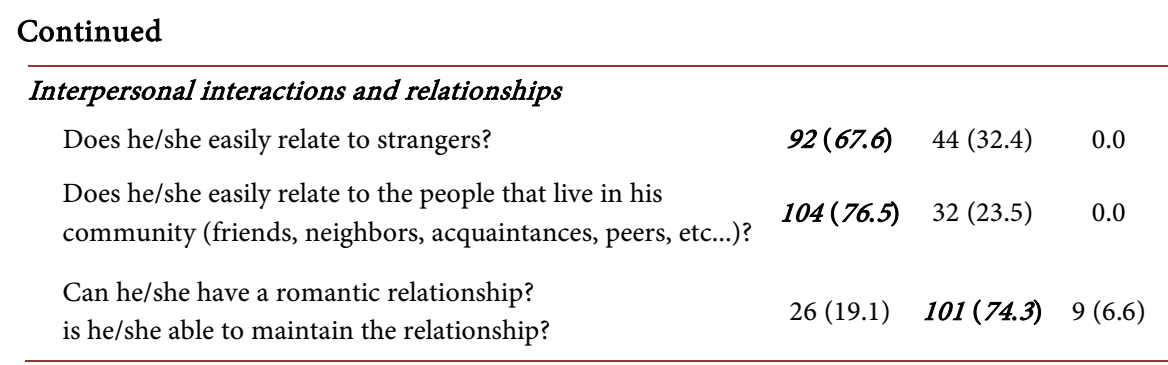

are not able to create and maintain a romantic relationship. A relevant fact concerns the present and past work experience of our reference sample. As many as $79.4 \%$ do not work and have never worked. Only $8.1 \%$ have worked in the past and only $5.1 \%$ now work. However, they are very engaged in the activities organized by the centers where they live or by their families.

\subsection{The Participation of the Person with DS in Social Life and in Activities within the Community Center}

In this section, the DOQuest investigates the participation of persons with DS in the activities promoted by the community centers (Table 5 ). In general, our sample is not involved in voluntary activities (69.9\%). Most of the persons with DS do not go to the cinema (47.1\%) and do not enjoy any sports (59.6\%). Regarding religion and spirituality, $53.7 \%$ of persons with DS do not relate with any kind of them. When asked which activities they perform in the community centers he/she is attending, it emerged that the principal activities are music therapy (31.6\%) and art and decorative activities (29.4\%) while the activities that they perform at home are mostly reading a book or a newspaper $(23.5 \%)$ and watching television (40.4\%).

\subsection{Environmental Factors}

The fourth section of the DOQuest is regarding the environmental factors (Table 6), in particular the use of support devices or the relational involvement. From a physical point of view, our sample does not need aids for personal use in daily life (84.6\%). Specifically, they do not need products of technology, mobility aids for personal indoor and outdoor mobility and transportation (79.4\%) and they do not need also any communication devices (72.1\%).

On the other hand, from a relational point of view, the majority $(84.6 \%)$ of our sample feels most comfortable with three or more persons. These persons are especially their mothers (25.0\%) or brothers and sisters (41.9\%).

\subsection{Future Planning}

In the last section of the questionnaire, dedicated to understanding the living conditions of people with DS, we explore the future perspective planned for them (Table 7). $25 \%$ of family members and health professionals said that there is not planning for the future of persons with DS. A lot of respondents stated that they have not thought of any actions for planning the future of the person 
Table 5. The participation of the person with DS in social life and in activities within the community center.

\begin{tabular}{|c|c|}
\hline Total sample N (136) & $\mathrm{N}(\%)$ \\
\hline \multicolumn{2}{|l|}{ The perceived level of independence } \\
\hline Completely & $4(2.9)$ \\
\hline Moderately & $57(41.9)$ \\
\hline A little & $53(39.0)$ \\
\hline Not at all & $20(14.7)$ \\
\hline Not applicable & $2(1.5)$ \\
\hline \multicolumn{2}{|l|}{ Does the person with DS work? Has hel she ever worked? } \\
\hline He/she works & $7(5.1)$ \\
\hline He/she doesn't work and he/she have never worked. & $108(79.4)$ \\
\hline He/she doesn't work, but he used to work in the past & $11(8.1)$ \\
\hline He did volunteer work or he/she volunteer in the community & $8(5.9)$ \\
\hline I wouldn't know & $2(1.5)$ \\
\hline \multicolumn{2}{|c|}{ Can the person with DS manage independently his/ her savings/ finances? } \\
\hline Completely & $0(0)$ \\
\hline Moderately & $4(2.9)$ \\
\hline A little & $20(14.7)$ \\
\hline Not at all & $112(82.4)$ \\
\hline \multicolumn{2}{|c|}{ Does the person with $D S$ volunteer in associations or in the community? } \\
\hline No & $95(69.9)$ \\
\hline Yes, habitually & $23(16.9)$ \\
\hline Yes, occasionally & $8(5.9)$ \\
\hline Actually no more & $4(2.9)$ \\
\hline He's not interested about it & $4(2.9)$ \\
\hline I wouldn't know & $2(1.5)$ \\
\hline \multicolumn{2}{|l|}{ Does the person with DS go to cinemas, museums, theatres? } \\
\hline No & $64(47.1)$ \\
\hline Yes, occasionally & $35(25.7)$ \\
\hline Yes, habitually & $17(12.5)$ \\
\hline Actually no more & $8(5.9)$ \\
\hline He's not interested about it & $8(5.9)$ \\
\hline I wouldn't know & $4(2.9)$ \\
\hline \multicolumn{2}{|l|}{ Does the person with DS play any sports? } \\
\hline No & $81(59.6)$ \\
\hline Yes, habitually & $17(12.5)$ \\
\hline Yes, occasionally & $16(11.8)$ \\
\hline Actually no more & $13(9.6)$ \\
\hline He's not interested about it & $8(5.9)$ \\
\hline I wouldn't know & $1(0.7)$ \\
\hline \multicolumn{2}{|l|}{ How does the person with DS relate to religion and spirituality? } \\
\hline No & $73(53.7)$ \\
\hline Yes, occasionally & $23(16.9)$ \\
\hline Yes, habitually & $19(14.0)$ \\
\hline
\end{tabular}




\section{Continued}

Actually no more

He's not interested about it

I wouldn't know

What are the daily activities of the person with this DS within the community center hel she is attending?

Music therapy

Art and decorative activities

Sewing class

Film viewing and discussing

Swimming

None

He doesn't attend any community center

Other

What kind of activities does the person with DS do when he/ she is at home or in other living situation?

$\mathrm{He} / \mathrm{she}$ watches television

$\mathrm{He} / \mathrm{she}$ reads a book/newspaper

Perform repetitive gestures, rituals

$\mathrm{He} /$ she calls friends and relatives.

$\mathrm{He} / \mathrm{she}$ uses the computer

I wouldn't know

Other

Table 6. Environmental factors: data about the physical and social environment the person with down syndrome lives in.

\begin{tabular}{lc}
\hline Total sample N (136) & N (\%) \\
\hline $\begin{array}{l}\text { Does the person with DS use assistive devices, in his/ her daily life } \\
\text { (for example contenitive diapers, etc.)? }\end{array}$ & $21(15.4)$ \\
$\quad$ Yes & $115(84.6)$ \\
$\quad$ No & \\
Does the person with DS need products of technology, mobility aids \\
for personal indoor and outdoor mobility and transportation \\
(for example, wheelchair, orthopedic shoes, limb prosthesis)? \\
$\quad$ Yes \\
$\quad$ No \\
$\begin{array}{l}\text { Does the person with DS need communication devices } \\
\text { (that help people to communicate and get information } \\
\text { for example devices to write and read, hearing aid, glasses, etc.)? } \\
\quad \text { Yes }\end{array}$ \\
$\quad$ No \\
$\begin{array}{l}\text { Thinking about people involved in the life of the person with DS, } \\
\text { how many of them the person with DS feels most comfortable with? } \\
\quad \text { None }\end{array}$ \\
$\quad$ One
\end{tabular}




\section{Continued}

\begin{tabular}{|c|c|c|c|}
\hline Two & & & $5(3.7)$ \\
\hline Three or more than three & & & $125(91.9)$ \\
\hline \multicolumn{4}{|l|}{ Who are those people? } \\
\hline \multicolumn{3}{|l|}{ Immediate Family: parents, brothers, sisters. } & $102(75.0)$ \\
\hline \multicolumn{3}{|l|}{ Extended family: uncles, aunts, nephews, nieces } & $12(8.8)$ \\
\hline \multicolumn{3}{|l|}{ Acquaintances, neighbors. } & $2(1.5)$ \\
\hline \multicolumn{3}{|l|}{ People that provide support or assistance } & $15(11.0)$ \\
\hline \multicolumn{3}{|l|}{ Friends } & $3(2.2)$ \\
\hline \multicolumn{3}{|l|}{ Other } & $2(1.5)$ \\
\hline \multicolumn{4}{|c|}{ Who is the reference person the person with DS feels most comfortable with? } \\
\hline \multicolumn{3}{|l|}{ Mother } & $34(25.0)$ \\
\hline \multicolumn{3}{|l|}{ Father } & $2(1.5)$ \\
\hline \multicolumn{3}{|l|}{ Both parents } & $3(2.2)$ \\
\hline \multicolumn{3}{|l|}{ Brother/s or sister/s } & $57(41.9)$ \\
\hline \multicolumn{3}{|l|}{$\begin{array}{l}\text { People that provide support or assistance } \\
\text { (social worker, psychologist, caregiver etc.) }\end{array}$} & $21(15.4)$ \\
\hline \multicolumn{3}{|c|}{ In the past his/her mother/father/health professional but actually no more } & $14(10.3)$ \\
\hline \multicolumn{3}{|l|}{ Other } & $5(3.7)$ \\
\hline \multicolumn{4}{|c|}{$\begin{array}{l}\text { Thinking about the person with } D S \text {, does he get any moral, physical, } \\
\text { emotional support from animals like pets (dogs, cats, birds, fish, etc.)? }\end{array}$} \\
\hline \multicolumn{3}{|l|}{ Yes } & $36(26.5)$ \\
\hline \multicolumn{3}{|l|}{ No } & $91(66.9)$ \\
\hline \multicolumn{3}{|l|}{ I wouldn't know } & $9(6.6)$ \\
\hline About the assistance network. & $\begin{array}{l}\text { Completely/ } \\
\text { Moderately } \\
\text { N (\%) }\end{array}$ & $\begin{array}{l}\text { A little/ } \\
\text { Not at all } \\
\mathrm{N}(\%)\end{array}$ & $\begin{array}{l}\text { I wouldn't } \\
\text { know } \\
\text { N (\%) }\end{array}$ \\
\hline $\begin{array}{l}\text { Are you satisfied with the housing management services } \\
\text { and policies offered for people with DS? }\end{array}$ & $47(63.9)$ & $39(28.7)$ & $50(36.8)$ \\
\hline $\begin{array}{l}\text { Are you satisfied with the public transport services } \\
\text { offered in your territory for adults with DS? }\end{array}$ & $51(37.5)$ & $53(39.0)$ & $32(23.5)$ \\
\hline $\begin{array}{l}\text { To what extent associations and organizations that have } \\
\text { something to do with the Down Syndrome has positively } \\
\text { affected the life of the person with DS? }\end{array}$ & $100(73.5)$ & $21(15.4)$ & $15(11.0)$ \\
\hline $\begin{array}{l}\text { Are you satisfied with the social security services or } \\
\text { policies offered in your territory for people with DS? }\end{array}$ & $54(39.7)$ & $66(48.5)$ & $16(11.8)$ \\
\hline $\begin{array}{l}\text { Are you satisfied with the health care services and } \\
\text { policies offered in your territory for adults with DS? }\end{array}$ & $67(49.2)$ & $52(38.2)$ & $17(12.5)$ \\
\hline $\begin{array}{l}\text { Are you satisfied with the education and training services } \\
\text { or policies offered in your territory for adults with DS? }\end{array}$ & $51(37.5)$ & $55(40.4)$ & $30(22.1)$ \\
\hline $\begin{array}{l}\text { Are you satisfied with the labor services and policies } \\
\text { offered in your territory for adults with DS }\end{array}$ & $29(21.3)$ & $64(47.1)$ & $43(31.6)$ \\
\hline $\begin{array}{l}\text { To what extent the heath care assistance offered in } \\
\text { your territory is able to provide assistance to } \\
\text { the person with DS? }\end{array}$ & $76(55.9)$ & $48(35.3)$ & $12(8.8)$ \\
\hline
\end{tabular}


Table 7. Future planning.

\begin{tabular}{|c|c|c|c|}
\hline & $\begin{array}{l}\text { People with } \\
\text { DS that } \\
\text { lives at home } \\
\mathrm{N}(\%)\end{array}$ & $\begin{array}{l}\text { People with } \\
\text { DS that } \\
\text { does not } \\
\text { live at home } \\
\mathrm{N}(\%)\end{array}$ & $\begin{array}{r}\text { Total } \\
\text { N (\%) }\end{array}$ \\
\hline \multicolumn{4}{|l|}{$\begin{array}{l}\text { Has caregiver already made a detailed planning } \\
\text { for the person with DS future? }\end{array}$} \\
\hline Yes & $48(35.5)$ & $41(30.1)$ & $89(65.6)$ \\
\hline No & $29(21.3)$ & $5(3.7)$ & $34(25.0)$ \\
\hline I don't know & $13(9.6)$ & $0(0.0)$ & $13(9.6)$ \\
\hline Total & $90(66.2)$ & $46(33.8)$ & $136(100.0)$ \\
\hline \multicolumn{4}{|l|}{$\begin{array}{l}\text { What actions have been taken to plan the } \\
\text { future of the person with DS? }\end{array}$} \\
\hline None. They collect information when it is the time & $26(19.1)$ & $16(11.8)$ & $42(30.9)$ \\
\hline I wouldn't know & $20(14.7)$ & $3(2.2)$ & $23(16.9)$ \\
\hline $\begin{array}{l}\text { Preliminary contacts have been taken with foster } \\
\text { homes or others health-related facilities }\end{array}$ & $15(11.0)$ & $18(13.0)$ & $33(24.3)$ \\
\hline $\begin{array}{l}\text { Some information have been requested to } \\
\text { people who have been in the same condition }\end{array}$ & $10(7.4)$ & $6(4.4)$ & $16(11.8)$ \\
\hline No one & $9(6.6)$ & $0(0.0)$ & $9(6.6)$ \\
\hline $\begin{array}{l}\text { Person with DS will remain at home with } \\
\text { brother or sister }\end{array}$ & $7(5.1)$ & $0(0.0)$ & $7(5.1)$ \\
\hline $\begin{array}{l}\text { Request of information to people who } \\
\text { had faced up to the same problems }\end{array}$ & $0(0.0)$ & $3(2.2)$ & $3(2.2)$ \\
\hline Other & $3(2.2)$ & $0(0.0)$ & $3(2.2)$ \\
\hline Total & $90(66.2)$ & $46(33.8)$ & $136(100.0)$ \\
\hline \multicolumn{4}{|l|}{$\begin{array}{l}\text { Even if no detailed planning for his/ her futt } \\
\text { has been made, where would caregiver like } \\
\text { or prefer him/ her to stay, and who would } \\
\text { caregiver like to look after him/her? }\end{array}$} \\
\hline $\begin{array}{l}\text { In his/her relative's house } \\
\text { (siblings, aunts and uncles, cousins, etc.) }\end{array}$ & $43(31.6)$ & $9(6.6)$ & $52(38.2)$ \\
\hline $\begin{array}{l}\text { In a group home with assistance from family } \\
\text { members and relatives } \\
\text { (brothers, sisters, uncles, aunts, cousins, etc.) }\end{array}$ & $18(13.2)$ & $18(13.2)$ & $36(26.5)$ \\
\hline $\begin{array}{l}\text { In an assisted-living facility with assistance } \\
\text { from family members and relatives } \\
\text { (brothers, sisters, uncles, aunts, cousins, etc.) }\end{array}$ & $9(6.6)$ & $11(8.1)$ & $20(14.7)$ \\
\hline I wouldn't know & $7(5.1)$ & $5(3.7)$ & $12(8.8)$ \\
\hline At home with a caregiver & $6(4.4)$ & $0(0.0)$ & $6(4.4)$ \\
\hline At home with one or more than one roommates & $5(3.7)$ & $0(0.0)$ & $5(3.7)$ \\
\hline $\begin{array}{l}\text { At home but next to a relative's house } \\
\text { (siblings, aunts and uncles, cousins, etc.) }\end{array}$ & $2(1.5)$ & $2(1.5)$ & $4(2.9)$ \\
\hline Other & $0(0.0)$ & $1(0.7)$ & $1(0.7)$ \\
\hline Total & $90(66.2)$ & $46(33.8)$ & $136(100.0)$ \\
\hline
\end{tabular}


with DS because they would collect information when it is the time (30.9\%). Some of them instead have taken preliminary contacts with foster homes or other health-related facilities (24.3\%). They also prefer to leave the person with DS in his/her relative's house or in a group with assistance from family members and relatives $(26.5 \%)$ and few of them prefer an assisted-living facility with assistance from family members and relatives (14.7\%). Finally, a lot of people with DS expressed the desire to continue their life with their family, together with their friends or with a partner.

\section{Discussion}

The present study belongs to a wider national Italian research aiming to spread the knowledge of the aging of people with DS and to identify the most important features in better future planning reported by a sample of 136 formal and informal caregivers (family members and health professionals) of people with DS over 45 years old. In accordance with the biopsychosocial perspective, we performed and administered an ad hoc questionnaire (DOQuest) which evaluated their health status, current state of their life, activity and participation domains, environmental factors and details about their future planning. Results provided significant information about how to plan their future taking into account their current life.

Most of the sample of people with DS do not have an educational qualification and receive a disability pension and attendance allowance. They live at home with a family member (parents or siblings) and attend a daily center, specifically a social care center; otherwise, people with DS who do not live at home live in a social health community for people with disabilities. Half of the sample changed the place where they live at least once in a lifetime, most often because parents passed away, and this occurrence caused important implications for future planning that future research might investigate [33]. Overall, family members contacted are mainly brothers or sisters and health professionals are most of all educators. This is different from other studies that usually involve parents, especially mothers. Little research focuses on people who were provided care of adult people with DS [27] [28]. Both studies remark on the importance to advise formal and informal caregivers about daily life activities and abilities for the future planning of ageing people with DS.

DOQuest also investigated the quality of life and the health conditions of the person with DS. Overall, family members and health professionals evaluated the perceived health status and quality of life of ageing people with DS as "good". About the perceived mental health status, respondents explained that in their opinion it had worsened gradually or it remained unchanged. In a longitudinal study conducted by Esbensen and colleagues [14], it was specified that people with DS were evaluated over a 9-year period. It was found that personal care skills declined more in adults with less severe intellectual disability while the skills of adults with more severe intellectual disability declined less. In contrast 
with these results, the study conducted by a group of researchers coordinated by Fonsecal [27] showed that behavioral changes precede or occur concomitantly with cognitive decline and it is confirmed by a lot of studies in this area [34] [35] [36]. Moreover, the respondents of the current study evaluated the perceived level of autonomy of people with DS as "enough" or "quite low". In a longitudinal analysis of a group of older adults with DS, it was explored that having better family relations may lead to more social connections and a greater maintaining independence in mobility and transportation. However, as we could see further on, the autonomy of our sample in mobility and transportation is very limited [32]. The last part of this section concerns the health conditions and the comorbidities that we could discover in the literature [17].

The third section of the DOQuest is about the capacity of the person with DS to perform tasks and actions and his/her involvement of typical life situations: they are able to do a simple task but they are not really able to plan their own daily routine. According to these results they are not able to take care of themselves, to take their medicine, to use any type of transportation and to prepare meals for themselves or for the others. In the 9-years study conducted by Esbensen [14], it is possible to see the changes in the functional abilities of people with DS. Specifically, in the period of the study, meal-related activities remain stable while skills in housekeeping improve. On the other hand, skills in personal care and mobility declined during this period. This lack of autonomy in the activities of daily living is probably due to an insufficient training for autonomy carried out by families or health operators [28] [29] [32]. In fact, it is so important to promote autonomy and social integration because adults with DS could develop their capacity to make choices among options, implementing decision and evaluating their effects [37]. In a study conducted in Rome with older people with DS [26] authors found that their quality of life was very poor, frequently characterized by limited autonomy and a dearth of social interactions [23]. In a recent qualitative study, twenty leaders in intellectual disability services in Sweden reported that "a prerequisite for healthy ageing for persons with intellectual disabilities is the opportunity to live according to their preferences and to make independent decisions. At the same time, they depend on individualized degrees of support from staff in order to make the most of this opportunity" ([38], pg. 4).

In the fourth section it is inquired the influence of the environmental factor in the daily life of people with DS. Family members and health operators consider that the persons with DS could have a better quality of life if they could use the services that are currently available for them. The importance of the environmental factors is stressed also in literature, in fact, there is ample evidence that developmental change is influenced by environmental factors such as family environment, social word, the opportunities that are available for individuals and supportive health care. For example, in a study carried out by Temple and colleagues [39] it was highlighted that more years of education predicted lower rates of Alzheimer's disease in people with DS. In another research [40] it was 
demonstrated that family cohesion and good quality of the mother-child relationship could predict growth in communication, daily living skills and socialization skills. So, we could say that family relations' impact on health, functional abilities and behavior problems and the family environment impact on the functioning of people with DS.

In addition, in our study it is considered the quality of the services turned to people with DS and their families. Both family members and health operators seem quite satisfied about social security services, social care services and education and training services.

The fifth part of the DOQuest is regarding the future of the person with DS. Here, family members and health professionals revealed that they have thought about the future but in concrete they have not acted yet or they have taken preliminary contacts with health-related facilities. When they think about the future, family members prefer that the persons with DS stay in their relative's house. This is a really important section of our study because the future perspective of older people with DS it has never been analyzed before. We tried to consider their future not only from an organizing point of view but as a perspective that family members and health operators hope [32] [38].

This study has some limitations. At first the DOQuest instrument is too long to be easily submitted to a very large sample. In addition, there is the necessity to validate the DOQuest to obtain generalizable measures. Another issue is concerning the sample that it is not representative, was selected by convenience so it is not well balanced between the different parts of Italy (the majority of responders live in the northern part of Italy). Despite of this, for the first time, it was possible to collect significant data on persons with DS over 45 years old with a holistic approach in relation to their future planning. In this perspective is really important take into account not only the health condition of persons with DS but also the environmental factors that characterized their lives. We remark that there is a lack of knowledge in the information of daily life activities of ageing people with DS in Italy [28] [32], because a great number of studies have focused on their physical and mental impairment. The aim of this study is also to fill this gap and investigate the involvement of people with DS in social activities. As Matthews and colleagues [37] recently stated, more quantitative data are required to accurately describe the abilities and potential of adults with DS (pg. 1389). Through the DOQuest it will be possible to collect important data, at the national and international level, for policymakers about how to prepare broad-spectrum interventions that are tailored to the actual and future needs of elderly people with DS. Validation of DOQuest is needed and future research will focus on this aim.

\section{Conclusions}

In conclusion, the results suggest two important essays: 1) it is important to plan the future of ageing people with DS in good time, and not only when it is neces- 
sary and unavoidable, so as to favor the continuity of skills acquired in adulthood avoiding a deterioration of their quality of life; 2) in concomitance of any change in their life (e.g. change of residence or level of independence due to a worsened health condition) it is mandatory to take into account not only their health conditions but also all the aspects that characterized their existence in a biopsychosocial view in order to better plan their present and future life. Henceforward, we invite to consider the disability of these people from a social and relational point of view and they cannot be treated just from a medical point of view. Following this direction, the information about the life contest and the environmental factors are really very important in order to plan tailored social-healthcare intervention.

\section{Acknowledgements}

Authors would like to thank the associations ANFFAS (Associazione Nazionale Famiglie di Persone con Disabilita Intellettiva e/o Relazionale) and AIPD (Associazione Italiana Persone Down) and all family members and health professionals who participated in the study.

\section{Conflicts of Interest}

No potential conflict of interest was reported by the authors.

\section{Funding}

The study was realized within the "DOSAGE Project: Functioning and disability measure of AGEing people with Down Syndrome: the creation of an instrument for a national and European implementation" that received the financial support of the Jerome Lejeune Foundation [Grant Number 1153-VC2013A].

\section{References}

[1] Parker, S.E., Mai, C.T., Canfield, M.A., et al. (2010) Updated National Birth Prevalence Estimates for Selected Birth Defects in the United States, 2004-2006. Birth Defects Research Part A: Clinical and Molecular Teratology, 88, 1008-1016. https://doi.org/10.1002/bdra.20735

[2] Dolk, H., Loane, M., Garne, E., et al. (2005) Trends and Geographic Inequalities in the Prevalence of Down Syndrome in Europe, 1980-1999. Revue d Epidémiologie et de Santé Publique, 53, 87-95. https://doi.org/10.1016/S0398-7620(05)84771-6

[3] Antonarakis, S.E., Lyle, R., Dermitzakis, E.T., et al. (2004) Chromosome 21 and down Syndrome: From Genomics to Pathophysiology. Nature Reviews Genetics, 5, 725-738. https://doi.org/10.1038/nrg1448

[4] Wang, Y., Mulligan, C., Denyer, G., et al. (2009) Quantitative Proteomics Characterization of a Mouse Embryonic Stem Cell Model of Down Syndrome. Molecular \& Cellular Proteomics, 8, 585-595. https://doi.org/10.1074/mcp.M800256-MCP200

[5] Bittles, A.H. and Glasson, E.J. (2004) Clinical, Social, and Ethical Implications of Changing Life Expectancy in Down Syndrome. Developmental Medicine \& Child Neurology, 46, 282-286. https://doi.org/10.1111/j.1469-8749.2004.tb00483.x

[6] WHO, Global Health and Aging, U.S. Department of Health and Human Services 
(2011) National Institutes of Health Publication.

[7] Bloom, B.E., Boersch-Supan, A., Mcgree, P., et al. (2011) Population Aging: Facts, Challenges, and Responses. Program on the Global Demography of Aging, Working Paper No. 71.

[8] Patja, K., Iivanainen, M., Vesala, H., et al. (2000) Life Expectancy of People with Intellectual Disability: A 35-Year Follow-Up Study. Journal of Intellectual Disability Research, 44, 591-599. https://doi.org/10.1046/j.1365-2788.2000.00280.x

[9] Penrose, L.S. (1949) The Incidence of Mongolism in the General Population. Journal of Mental Science, 95, 685-688. https://doi.org/10.1192/bjp.95.400.685

[10] Glasson, E.J., Sullivan, S.G., Hussain, R., et al. (2002) The Changing Survival Profile of People with Down's Syndrome: Implications for Genetic Counselling. Clinical Genetics Clinical Genetics, 62, 390-393. https://doi.org/10.1034/j.1399-0004.2002.620506.x

[11] Bittles, A.H., Bower, C., Hussain, R., et al. (2006) The Four Ages of Down Syndrome. European Journal of Public Health, 17, 221-225. https://doi.org/10.1093/eurpub/ckl103

[12] Roth, G.M., Sun, B., Greensite, F.S., Lott, I.T. and Dietrich, R.B. (1996) Premature Aging in Persons with Down Syndrome: MR Findings. American Journal of Neuroradiology, 17, 1283-1289.

[13] Coppus, A.M., Evenhuis, H.M., Verberne, G.J., et al. (2008) Survival in Elderly Persons with Down Syndrome. Journal of the American Geriatrics Society, 56, 2311-2316. https://doi.org/10.1111/j.1532-5415.2008.01999.x

[14] Esbensen, A.J., Seltzer, M.M. and Krauss, M.W. (2008) Stability and Change in Health, Functional Abilities, and Behavior Problems among Adults with and without Down Syndrome. American Journal on Intellectual and Developmental Disabilities, 113, 263-277. https://doi.org/10.1352/0895-8017(2008)113[263:SACIHF]2.0.CO;2

[15] Janicki, M.P. and Wisniewski, H.M. (1985) Aging and Developmental Disabilities-Issues and Approaches. Oxford Brookes University, Baltimore.

[16] Covelli, V., Raggi, A., Meucci, P., et al. (2015) Ageing of People with Down Syndrome: A Literature Review from 2000 to 2014. International Journal of Rehabilitation Research, 39, 20-28. https://doi.org/10.1097/MRR.0000000000000147

[17] Danes, C.F. (2012) Specific Aspects of Ageing in Down's Syndrome. Revista Medica Interacional Sobre el Sindrome de Down, 16, 3-10. https://doi.org/10.1016/S1138-2074(12)70018-0

[18] Carr, J. (2000) Intellectual and Daily Living Skills of 30-Year-Olds with Down's Syndrome: Continuation of a Longitudinal Study. Journal of Applied Research in Intellectual Disabilities, 13, 1-16. https://doi.org/10.1046/j.1468-3148.2000.00003.x

[19] Hawkins, B.A., Eklund, S.J., James, D.R., et al. (2003) Adaptive Behavior Cognitive Function of Adults with Down Syndrome: Modeling Change with Age. American Journal of Mental Retardation, 41, 7-28. https://doi.org/10.1352/0047-6765(2003)041<0007:ABACFO>2.0.CO;2

[20] Fonsecal, L.M., De Oliveira, M.C., De Figueiredo, F., Guilhoto, L.M., et al. (2014) Bereavement and Behavioral Changes as Risk Factors for Cognitive Decline in Adults with Down Syndrome. Neuropsychiatric Disease and Treatment, 10, 2209-2219. https://doi.org/10.2147/NDT.S68831

[21] Brown, R., Taylor, J. and Matthews, B. (2001) Quality of Life-Ageing and Down Syndrome. Down Syndrome Research and Practice, 6, 111-116.

https://doi.org/10.3104/case-studies.101 
[22] Brown, I. and Brown, R.I. (2009) Choice as an Aspect of Quality of Life for People with Intellectual Disabilities. Journal of Policy Practice in Intellectual Disabilities, 6 , 11-18. https://doi.org/10.1111/j.1741-1130.2008.00198.x

[23] Furniss, K.A., Loverseed, A., Loppold, T., et al. (2012) The Views of People who Care for Adults with Down's Syndrome and Dementia: A Service Evaluation. British Journal of Learning Disabilities, 40, 318-327. https://doi.org/10.1111/j.1468-3156.2011.00714.x

[24] Werner, S., Edwards, M., Baum, N., et al. (2009) Family Quality of Life among Families with a Member who Has an Intellectual Disability: An Exploratory Examination of Key Domains and Dimensions of the Revised FQOL Survey. Journal of Intellectual Disability Research, 53, 501-511. https://doi.org/10.1111/j.1365-2788.2009.01164.x

[25] Newton, R. (2018) Quality of Life in Down Syndrome: A Matter of Perspective. Developmental Medicine \& Child Neurology, 60, 337-338. https://doi.org/10.1111/dmcn.13706

[26] Bertoli, M., Biasini, G., Calignano, M.T., et al. (2011) Needs and Challenges of Daily Life for People with Down Syndrome Residing in the City of Rome, Italy. Journal of Intellectual Disability Research, 55, 801-820. https://doi.org/10.1111/j.1365-2788.2011.01432.x

[27] Matthews, T.J., Allain, D.C., Matthews, A.L., et al. (2018) An Assessment of Health, Social, Communication, and Daily Living Skills of Adults with Down Syndrome. American Journal of Medical Genetics Part A, 176, 1389-1397. https://doi.org/10.1002/ajmg.a.38721

[28] Covelli, V., Raggi, A., Meucci, P., et al. (2015) A Pilot Study on Functioning and Disability of Aging People with Down Syndrome in Italy. Journal of Policy and Practice in Intellectual Disabilities, 12, 303-311.

[29] WHO (2001) The International Classification of Functioning, Disability and Health: ICF. World Health Organization, Geneva.

[30] Stucki, G., Cieza, A. and Melvin, J. (2007) The International Classification of Functioning, Disability and Health: A Unifying Model for the Conceptual Description of the Rehabilitation Strategy. Journal of Rehabilitation Medicine, 39, 279-285.

https://doi.org/10.2340/16501977-0041

[31] Foley, S. (2012) Reluctant "Jailors" Speak out: Parents of Adults with Down Syndrome Living in the Parental Home on How They Negotiate the Tension between Empowering and Protecting their Intellectually Disabled Sons and Daughters. British Journal of Learning Disabilities, 41, 304-311. https://doi.org/10.1111/j.1468-3156.2012.00758.x

[32] Covelli, V., Raggi, A., Paganelli, C. and Leonardi, M. (2018) Family Members and Health Professionals' Perspectives on Future Life Planning of Ageing People with Down Syndrome: A Qualitative Study. Disability and Rehabilitation, 40, 2867-2874. https://doi.org/10.1080/09638288.2017.1362595

[33] Patti, P., Amble, K. and Flory, M. (2010) Placement, Relocation and End of Life Issues in Aging Adults with and without Down's Syndrome: A Retrospective Study. Journal of Intellectual Disability Research, 54, 538-546. https://doi.org/10.1111/j.1365-2788.2010.01279.x

[34] Holland, A.J., Hon, J., Huppert, F.A. and Stevens, F. (2000) Incidence and Course of Dementia in Individuals with Down's Syndrome: Findings from Population-Base Study. Journal of Intellectual Disability Research, 44, 138-146. https://doi.org/10.1046/j.1365-2788.2000.00263.x 
[35] Ball, S.L., Holland, A.J., Hon, J., et al. (2006) Personality and Behaviour Changes Mark the Early Stages of Alzheimer's Disease in Adults with Down's Syndrome: Findings from a Prospective Population-Based Study. International Journal of Geriatric Psychiatry, 21, 661-673. https://doi.org/10.1002/gps.1545

[36] Deb, S., Hare, M. and Prior, L. (2007) Symptoms of Dementia among Adults with Down's Syndrome: A Qualitative Study. Journal of Intellectual Disability Research, 51, 726-739. https://doi.org/10.1111/j.1365-2788.2007.00956.x

[37] Faulks, D., Collado, V., De Freminville, B., et al. (2006) A Controlled National Survey in France of Health-Related Challenges for Persons with Down Syndrome. Nursing Outlook, 54, 345-352. https://doi.org/10.1016/j.outlook.2006.09.004

[38] Johansson, M., Björne, P., Runesson, I. and Ahlström, G. (2017) Healthy Ageing in People with Intellectual Disabilities from Managers' Perspective: A Qualitative Study. Healthcare (BaseI), 5, 45. https://doi.org/10.3390/healthcare5030045

[39] Temple, V., Jozsvai, E., Konstantareas, N.M. and Hewitt, T.A. (2001) Alzheimer dementia in Down's Syndrome: The Relevance of Cognitive Ability. Journal of Intellectual Disability Research, 45, 47-55.

[40] Hauser-Cram, P., Warfield, M.E., Shonkoff, J.P., et al. (1999) Family Influences on Adaptive Development in Young Children with Down Syndrome. Society for Research in Child Development, 70, 979-989.

https://doi.org/10.1111/1467-8624.00071 